\title{
The thinking about the College adult education transformation development in the new period
}

\author{
Dong $\mathrm{Ma}^{1, \mathrm{a}}$ \\ ${ }^{1}$ Jilin Agricultural University, Changchun, Jilin Province, China \\ amadong8487@163.com
}

Keywords: New period, Colleges and universities, Adult education, Transformation, Development

\begin{abstract}
As people the importance of improving the education industry, the development of adult education also got great progress. The current China's adult education cause has made outstanding achievements, but we also need to face a series of problems now. This paper will be based on the current new period under the background of great crisis and challenges facing China's adult education management is analyzed, and put forward concrete opinions or Suggestions, contribute to the development of Chinese adult education.
\end{abstract}

\section{Introduction}

Adult the university entrance exam is a national education series, listed in the national enrollment plan, the country admits record of formal schooling, attend unified exam national enrollment, admission to the unified organization of the provinces, autonomous regions [1]. Teaching methods can be divided into three types of full-time, part-time, and correspondence, the examinee should according to their own situation to choose suitable for their own learning style.

Since 1965, when the French famous adult education expert Paul Lengr and formally after the viewpoint of lifelong education, which caused a strong reaction in the world. Rise and development of lifelong education thought, has a profound impact on adult higher education [1]. In the framework of lifelong education in the construction of the new idea of adult higher education has become the consensus of people, set up under the framework of lifelong education, the adult higher education system, promote the establishment of a learning society, that has become the mainstream in the adult higher education in the world, many countries has also become the basic principles of adult higher education curriculum reform.

With the economic and social development, a concept of life-long education and social demands for education continued to deepen, China's adult higher education is carrying on the transformation, a series of related adult the operators and the running forms, must be made or ahead of this a series of transformation patterns, adult higher education schools can be truly human development platform, adult higher education school is likely to get sustainable development [1]. From the present situation and development trend of adult higher education is concerned, China's adult higher education is undergoing a transformation.

\section{The crisis and challenge Chinese adult education facing in the new period}

Adult education and we know compared to the traditional school education and lifelong education has more obvious different, we can also see it as organic combination of the traditional school education and lifelong education [2].It not only selected the traditional school education teaching form, and will extend the time of education work to the educatees at various stages of life.Older social personnel for adult education provides a good opportunity to learn, but also improve its accept the education environment.From this we can see that the adult education to the current social training work has very important significance.

The opportunities China's adult education facing. Currently China has entered the information era, all kinds of sophisticated talent demand is increasing. But because is now working at a young age and no conditions received a good education, and so many workers professional quality is not high, in the workplace is often rely on their own for many years accumulate the experience to solve practical 
production problems. This situation not only affects the further development of social productivity at present, and will increase the probability of all kinds of production accidents. While the existence of the adult education can be connected to vocational education, to form a more complete and reasonable education system, demand for higher areas of high-quality talent. That can say that the adult education largely improve the overall quality of the workers of the whole social production activities, make it have the necessary professional skills in work and accomplishment, in order to meet the production requirements of growing [2].In this context, the adult education must attach great importance to, and continuously perfect. Only adult education work can play a maximum utility, can let the current labor personnel quality is low and the society get perfect solution to the contradiction between the demands for higher productivity.

The challenges China's adult education facing. Although China's adult education development foreground is very wide, but in the current adult education management work still exist many problems, and these problems largely affected the embodiment of the adult education efficiency. First, adult education has a very important role for the current social and economic development, but compared with the mainstream education form, it is still at a disadvantage. The most important thing is embodied in the education investment, education funds for the most part in China are used in nine-year compulsory education and higher education field, and the money is limited in the field of adult education [2]. The great extent, restricts the further development of adult education work, not only make the adult education faculty is not enough is enough, at the same time also can't provide the corresponding education teaching facilities, to meet the needs of the daily teaching. Second, adult education is the most teachers in the school of old technical secondary school graduates, many people even do not have the education teaching qualification. This kind of adult education teachers teaching experience is very little, or before and there is no experience working in the field of education. Most of the teachers' teaching way too old, cannot be combined with the latest scientific research results; Some is teaching content is too boring, will not be able to attract students; And is not prepared for the good work before teaching, the students can't better access to knowledge, which will make the effect of the adult education is affected by the larger. Finally, adult education relatively special object, which is mostly enterprise on-the-job personnel, work is relatively busy at ordinary times, can be used to study time is very limited [2]. After a hard day's work, a lot of people also can appear school-weary psychology. Most of the current adult education school attendance and no more specification for teaching system, so that make the education teaching activities more and more become a mere formality. Within the school teaching atmosphere become weak gradually, the teacher lost his lecture teaching, and students also lost the confidence of learning. This will certainly form a vicious circle, make adult education lose proper role.

\section{The transformation of colleges and universities adult education in the new period}

At present, in some economically developed areas, has been the dominant utilitarian value orientation of adult higher education is no longer so obvious, but turned to the recessive demand of leisure education, the pursuit of utility.As life improvement of living standards, people demand for cultural development of education, to accept the value orientation of adult continuing education is also in transition.From the present situation and development trend of adult higher education is concerned, China's adult higher education is undergoing a transformation.

From the education needs to demand education transformation. Within 20 years after the reform and opening up, China's adult higher education is a kind of education demand patterns, namely ordinary education supply can not meet the needs of economic and social development, the outside of the normal education is emerging adult higher education, it is the need of national economic and social development, is also the needs of the development of education, or by the state education departments formulate relevant policies and regulations on education, education training mode, payment standard, etc., the school is only responsible for organizing the implementation of education and management, is a typical model of education demand [3]. Which has both the demand of the record of formal schooling education, and has the requirements such as pre-service training, skills, technology re-education, mainly degree requirements, related to the model of adult higher 
education self-study exam, correspondence, community college, adult full-time or bases, pre-service training, such as model, the model of adult higher education is the school choose to college to accept education, implementing the education demand is everything the top-down model of education.

Thus, adult higher education from education demand to the education demand, or from the national political and economic development needs of adult continuing education transformation for individual choice self-development needs of adult continuing education mode, is individual development needs of the adult higher education, adult higher education is the needs of individual education decides the development model of education demand.

From pure academic education to a variety of training needs transformation. The purpose of the establishment of adult higher education in China is to enhance the degree of some on-the-job personnel, skills, and alleviate the problem of shortage of general education resources, the adult higher education in the 20 years after the end of last century, as many on-the-job personnel qualifications and the theoretical level of ascension has been played a role, the corresponding mode of adult education is a reference to ordinary schools school-running mode, the vast majority of adult higher education is completely pure degree promote education, educational form is single.In adult higher education and general higher education, according to the quota issued by the competent department of education, after a high exam, according to the test scores from high to low [3]. Of adult higher education school, school system, curriculum and so on also refer to ordinary schools school educational system, completed the relevant courses of study, the relevant diploma awarded, the vast majority of adult school besides degree promote education, there are few other forms of education.

On the other hand to take the bull attack, relying on the strength of the parent school professional or social a frontier trade, etc., held a variety of qualifications examination classes or raise short-term training skills technology, this kind of mode of adult education has become the mainstream of adult higher education educational model in eastern, it will be the next important trend in the development of adult higher education schools in the country.

From the pursuit of economies of scale transformation to the boutique benefits. In the $1990 \mathrm{~s}$, the adult higher education degree to promote education, can be said to be in full swing, the number of students in the adult school less tens of thousands of people, more than hundreds of thousands of people.Schools to deal with the record of formal schooling education are inundated with ascension, there is no time and energy to hold other adult higher education.

With deepening of ordinary education enrollment expansion and the death of the height of adult education promotion education demand, need through the adult higher education to increase the number of degrees has been shrinking fast., has a look ahead of the transformation of adult higher education school began school, from the pursuit of economies of scale transformation to the pursuit of high-quality goods benefit [3]. The pursuit of high-quality goods school idea has two trends: one is from the original upgrade this specialized subject qualification education to graduate student degree education transformation, such as some schools of GCT, EMBA, MPA, MBA, etc., from the original postgraduate department (department, school) as a graduate student enrollment management transformation in joint and adult higher education college admission management, adult higher education of individual schools and even started $\mathrm{PhD}$ program admissions;Secondly, the eastern developed areas of adult higher education schools rely on maternal strong professional or social demand industry, carry out frontier or social sought-after professionals of short-term training, bull attack, priority support, makes the high-quality goods of adult higher education professional training or the content, the road to the quality of adult higher education training school will be the general trend of adult higher education development in the future.

From a single degree education needs to self development direction of multi-level demand education transformation. There is no denying that, before this century most of adult higher education is a kind of record of formal schooling education demand, the reason is: on the one hand, because the adult work unit of talent evaluation mechanism, rank with explicit compensation, the promotion, unit caused by soft power mechanisms such as the symbol of education needs [2]. On the other hand, because the social climate of diploma of employment mechanism, leading to a lower no corresponding diploma or degree of adults have to improve their qualifications, the phenomenon of 
adult higher education present in the less developed economy in the western region have a certain market.

From the specified compulsory course to students choose course selection. Traditional curriculum design of adult higher education, especially in the adult higher education curriculum design of ascension are almost always reference or copy of ordinary full-time college curriculum design, students only when teaching plan, test qualified, to obtain the corresponding certificate or diploma [4]. As long as there is a section is not completed or failed the make-up exam, school examination had not closed, not only is the verification by the competent department of education could not have passed, is in line with the adult higher education curriculum design requirements, no inspection and evaluation.

Adult higher education development to the present, still in use for courses of adult higher education schools have in a quick adjustment of curriculum structure and revision, the every adult college with a forward-looking vision through a variety of research, field trips, invite relevant celebrities and proposed plans to accept adult continuing education students to design related courses and training programs, some adult school students offer way, etc., emerged in the school are required to offer relevant curriculum, lesson plans, teaching teachers, evaluation method, etc., the corresponding of the adult education school students and the school benefit will present the flourishing trend.Students participation in the selection, design course is accord with the law of education, but also the inevitable developing trend of adult higher education.

Teaching from the tuitional school suggested diagnosis type transformation. Chinese traditional teaching methods are basically teaching method, content is the basic content of the teaching material, especially in the peak number of adult higher education students and implements the era of big class teaching, practice teaching method, not only in that within a few hours to complete a kind s of teaching tasks, the trunk course of adult higher education individual teacher didn't teach, but paint test points, key, help students to find the examination content, and also is more students for diploma and diploma to accept the adult re-education [4]. Relevant teaching management present a "sell school diploma, students pay for diploma" of the class don't speak, don't grant, not learn of adult teaching way in my life.

From the transformation period to consultation hours. From traditional Chinese adult higher education, are almost always refer to the ordinary full-time school courses related to set the length of time (hours), especially enhance education of record of formal schooling, more of a reference or copy the relevant full-time college school system to develop, even the self-study exam, correspondence, community is no exception [5]. Although in some sense this can guarantee the students' learning harvest, but relatively have jobs and has a longer working life of adult students, is not realistic, because of the foundation, the basic knowledge and skills, students may not be less than teachers know, compulsory school can cause students truancy, absence of further deterioration of the phenomenon such as.

Adult higher education healthy development of the school had already started teaching content, teaching teachers in consultation with students and teaching time limit (class), etc., some of the adult higher school the consultation period is defined as "flexible hours", namely the related contents of chapter teaching plan in advance students, students Suggestions are put forward according to the general teaching time and adjust the class time [5]. The consultation hours mechanism also demands for the certificate of the adult education needs to provide a beneficial attempt, from the development trend of China's adult higher education, consultation hours mechanism will become the main system of adult higher education in the future.

From the utilitarian education demand to leisure demand education transformation. From participants for the demand of education, China in the past most of the adult higher education is a clear dominant utilitarian education demand orientation, namely buy on continuing education's purpose is to hope to provide career development effective safeguard, both degree enhance education and professional skills, technical training, to spend money to accept continuing education's purpose is to revenue-generating potential economic value, at the very least, is the opportunity to gain [5]. Of 
course, once the students have a direct utility demand, corresponding of adult higher education is to develop the market.

\section{Summary}

Adult education work's contribution to the society is very large, in order to be able to make adult education in the process of China's social and economic development contribute greater contribution, we must to solve the current problems existing in the adult education management, adult education will become a mere formality, can't really play a role. At the same time, we also want to put our heads together, such as organizing experts and scholars in view of the current adult education management problems of conducting seminars, or with other adult school academic communication, etc. These for the standardization of the Chinese adult education management and rationalization have a very important role.

\section{References}

[1] S.Ch. Chang, The present situation and development of university adult education management, Management and Technology of SME, 2015, pp.9-12.

[2] K.L. Li, Under the background of the new normal adult education management, Journal of Beijing Xuanwu Hongqi Spare - Time University, 2015, vol.4, pp.22-25.

[3] D.H. Li, The education from the view of the elements of building a harmonious society, Education research, 2005, vol.9, pp.39-42.

[4] G.H. Wei, Adult higher education reform and innovation of teaching methods, Continue education research, 2011, vol.11, pp.51-54.

[5] H.Wang and Ch.D. Zhao, Continuing education in higher vocational colleges research, Cultivating creative personnel to continue education research, 2013, vol.1, pp.45-46. 